Meta

Journal des traducteurs

Translators' Journal

\title{
The Role of Coherence in Text Approaching and Comprehension: Applications in Translation Didactics
}

\section{Georgia Kostopoulou}

Volume 52, numéro 1, mars 2007

Traductologie : une science cognitive

URI : https://id.erudit.org/iderudit/014729ar

DOI : https://doi.org/10.7202/014729ar

Aller au sommaire du numéro

Éditeur(s)

Les Presses de l'Université de Montréal

ISSN

0026-0452 (imprimé)

1492-1421 (numérique)

Découvrir la revue

Citer cet article

Kostopoulou, G. (2007). The Role of Coherence in Text Approaching and Comprehension: Applications in Translation Didactics. Meta, 52(1), 146-155. https://doi.org/10.7202/014729ar
Résumé de l'article

L'approche de la linguistique communicative du texte des études de textes et de leurs problèmes théoriques et méthologiques jouent un rôle important dans la traductologie et dans la didactique de la traduction. Le besoin d'utiliser des facteurs textuels dans le processus de la translation et de l'enseignement est visible dans les diverses théories linguistiques et translationnelles, étant entendu que la translation, acte de parole et de communication, ne se déroule pas au niveau de la langue, mais à celui du texte et du discours en utilisant à la fois le linguistique et l'extralinguistique.

Cet article étudie l'un des sept facteurs textuels selon la théorie de base de Beaugrande et Dressler, c'est-à-dire le facteur de cohérence. Étant donné que la cohérence exprime la constante logique des énoncés en terme de contenu - et par conséquent la construction du sens - les concepts de connaissance, de modes et de types de savoir, des cadres et scénarios, mémoire, sont importants pour décrire et examiner ce facteur dans l'approche de la compréhension du texte. De plus, l'interconnexion de la linguistique du texte de la translation et de la cognition est évidente en prenant en compte l'argument de Beaugrande (1999) que « la linguistique du texte a toujours eu une orientation résolument cognitive parce que le texte doit être décrit à la fois comme produit et processus ». Par ailleurs, nous examinons comment les enseignants de la translation intègrent ces concepts et ces éléments dans leurs choix de textes à traduire, et comment ils utilisent la théorie de la haute et la faible cohérences textuelles (D. McNamara) pour servir aux apprentis translateurs à mettre en valeur leurs connaissances extralinguistiques et à utiliser leurs connaissances préalables lors de la phase de compréhension, décodage de l'acte de translation.
Ce document est protégé par la loi sur le droit d'auteur. L'utilisation des services d'Érudit (y compris la reproduction) est assujettie à sa politique d'utilisation que vous pouvez consulter en ligne.

https://apropos.erudit.org/fr/usagers/politique-dutilisation/ 


\title{
The Role of Coherence in Text Approaching and Comprehension: Applications in Translation Didactics
}

\author{
GEORGIA KOSTOPOULOU \\ Ionian University, Corfu, Greece \\ kostopoulou@dflti.ionio.gr
}

\section{RÉSUMÉ}

L'approche de la linguistique communicative du texte des études de textes et de leurs problèmes théoriques et méthologiques jouent un rôle important dans la traductologie et dans la didactique de la traduction. Le besoin d'utiliser des facteurs textuels dans le processus de la translation et de l'enseignement est visible dans les diverses théories linguistiques et translationnelles, étant entendu que la translation, acte de parole et de communication, ne se déroule pas au niveau de la langue, mais à celui du texte et $d u$ discours en utilisant à la fois le linguistique et l'extralinguistique.

Cet article étudie l'un des sept facteurs textuels selon la théorie de base de Beaugrande et Dressler, c'est-à-dire le facteur de cohérence. Étant donné que la cohérence exprime la constante logique des énoncés en terme de contenu - et par conséquent la construction du sens - les concepts de connaissance, de modes et de types de savoir, des cadres et scénarios, mémoire, sont importants pour décrire et examiner ce facteur dans l'approche de la compréhension du texte. De plus, l'interconnexion de la linguistique du texte de la translation et de la cognition est évidente en prenant en compte l'argument de Beaugrande (1999) que «la linguistique du texte a toujours eu une orientation résolument cognitive parce que le texte doit être décrit à la fois comme produit et processus ». Par ailleurs, nous examinons comment les enseignants de la translation intègrent ces concepts et ces éléments dans leurs choix de textes à traduire, et comment ils utilisent la théorie de la haute et la faible cohérences textuelles (D. McNamara) pour servir aux apprentis translateurs à mettre en valeur leurs connaissances extralinguistiques et à utiliser leurs connaissances préalables lors de la phase de compréhension, décodage de l'acte de translation.

\footnotetext{
ABSTRACT

The communicative text-linguistic approach to the study of texts and their theoretical and methodological problems plays an important role in Translation Studies and in Translation Didactics. The need to use and utilise the textual factors in the translation process and teaching is apparent in various linguistic and translational theories given that Translation, an act of speech and communication, is not performed at the level of language, but at the level of the text and discourse, utilising both linguistic and extralinguistic devices.

This paper examines one of the seven textual factors, according to the basic theory of de Beaugrande and Dressler, i.e., the factor of coherence. Given that coherence expresses the logical consistency of utterances in terms of content - and therefore the construction of meaning - concepts such as knowledge, patterns and types of knowledge, frames and scripts, memory, are crucial for describing and examining this factor when approaching and understanding a text. Moreover, the interconnection of text linguistics, translation and cognition is evident, considering de Beaugrande's argument (1999) that "text linguistics has always had a resolutely cognitive orientation because the text must be described as both product and process."
} 
Furthermore, we shall examine how teachers of translation courses may take into account these concepts and elements when choosing texts for translation purposes, and utilise the theory of high-coherence and low-coherence texts (D. McNamara) in order to assist translator trainees in enhancing their extralinguistic knowledge and in using their prior knowledge during the comprehension/decoding phase of the translation act.

\section{MOTS-CLÉS/KEYWORDS}

coherence, commonsense knowledge, text-based knowledge, cognitive resources, script

Before analysing the concept of coherence and its relation to translation and cognitive sciences, emphasis must also be placed on the interdisciplinary character of Translatology or Translation Studies, a term introduced by J. Holmes in 1972 in his paper "The name and nature of Translation Studies," indicating the interconnection of translation with many other scientific fields (Hatim and Munday 2004: 7-9). Moreover, recent research, e.g., Hatim and Munday (2004), Williams and Chesterman (2002), outlines this interdisciplinarity, making evident that there are still many domains for research. Also, in relation to cognitive sciences and cognitive psychology, of particular interest are the fields of text analysis and translation; translation quality assessment; translator training; and, of course, translation and technology.

Of course, the relation between Translation Studies and Cognitive Sciences is not recent. Cognitive, but mainly psycholinguistic approaches to the translation process and its mechanisms have been the focus of research in the past decades (indicatively, the models of Krings, Königs, Lörscher, Koller, Kiraly) with an orientation to translation didactics and pedagogy. The most known approach which was used in this regard is the introspective method, with its main tool being the so-called Think Aloud Protocols (TAPs), a method of orally presenting the translator's thoughts on the text to be translated, at the moment they are generated. ${ }^{1}$

Many interesting views on issues about cognitive linguistics and their relation to translation process are known, such as the role of TAPs, new perspectives with eyetracking systems, etc. Our paper presents a topic within the context of the communicative text-linguistic approach, which investigates the communicative function of texts by examining the goals they pursue within specific communicative conditions and the goals they really achieve, and by stressing also the importance of the experiences of both the producer and the receiver of individual texts. Moreover, the interconnection of text linguistics, translation and cognition is evident in Beaugrande's phrasing (1999) "text linguistics has always had a resolutely cognitive orientation because the text must be described as both product and process."

According to the basic theory of Beaugrande and Dressler, coherence is a textual factor which "concerns the ways in which the components of the textual world, i.e., the configuration of concepts and relations which underlie the surface text, are mutually accessible and relevant" (1981: 4). When referring to concepts and relations, we automatically refer to meanings. Each sentence conveys meanings, thus forming a sort of continuity of senses, so that the reader/receiver of the message can follow the chain of information and track the threads of senses, back and forth. According to Beaugrande and Dressler, important points for examining coherence are the control centres, which consist of primary and secondary concepts forming a conceptual network, which the reader should discover in order to process and interpret a message. 
But when does a message, a text, an utterance make sense? Let us recall some relevant questions raised by Bell (1991: 166) which are important for the translator: "(a) which world are we attempting to match with the text, given the subjectivity of personal experience, the certainty that different cultures perceive (or, at least, model) the world differently?; (b) how can we act upon the realization of the highly interactive nature of text?; and (c) how can we come to any principled understanding of text-processing, unless we find ways of relating 'real world' and 'text world' together in a way which 'makes sense' for us?"

The textual world, however, does not always match, or does not always reflect the real world, the extra-textual world. Besides, textual worlds include, but also require many more elements than the meanings of the surface text expressions in order to be understood: cognitive processes activate the so-called commonsense knowledge, which derives from the expectations and experiences of the parties involved in the communicative process with regard to the organisation of events and situations. Therefore, knowledge of the real world, even at a minimum level, no matter how subjective it can be, is a precondition of comprehension. Combined with common sense, it assists text users in controlling the degree to which the textual world converges with or deviates from the real world. Therefore and within the framework of communication, a comparison of these two worlds takes place; the bigger the deviation, the higher the interest regarding the presence or absence of the coherence factor, namely the logical connection of utterances (Beaugrande and Dressler 1981: 4, 84-86).

So, how is meaning constructed? How are we able to understand the content of an utterance? When is a message coherent or incoherent? Constructing and organising textual worlds is an everyday activity in human communication and interaction, and the differentiation and variety of concepts and meanings are reduced or limited, especially in specific communicative settings.

At this point, it could be useful also to refer to certain notions related to the description of coherence. First, the two types of knowledge that help us in the construction of meaning and are crucial for communication are declarative knowledge, namely what we know, and procedural knowledge - how something is done. But how is knowledge stored and utilised? Endel Tulving suggested the notions of episodic memory, which "contains the records of one's own experience" and semantic memory "which reflects the inherent patterns of the organization of knowledge" (Beaugrande and Dressler 1981: 89).

In relation to translation and text comprehension, many scholars refer to knowledge and the types of knowledge a translator should possess.

With regard to the translation process and translators' training, Daniel Gile (1995: 84-85) refers to the contribution of extralinguistic knowledge to text comprehension. In this sense, "extralinguistic knowledge can be broken down into two subcategories: preexisting ELK, and knowledge acquired from the Text itself, or contextual knowledge. A minimum of preexisting ELK is necessary in order to disambiguate the sourcelanguage text and select the proper target-language equivalents."

Roger Bell (1991: 112-113, 206-207) underlines the two aspects of "shared knowledge" referring to the situation and the context of an utterance: (a) the linguistic knowledge, i.e., "internalized knowledge of the rule systems governing the code" which, in particular, includes "co-textual knowledge which allows the communicator to refer 
back and forth through the unfolding text itself." Linguistic knowledge is further distinguished into syntactic, semantic and pragmatic knowledge. (b) the social knowledge, i.e., "internalized knowledge of the conventions which constrain and regulate the application of the shared 'ground-rules' for communication in operation in a speech community," which includes "contextual knowledge" which in turn helps the translator to classify a text to a type and a genre and attribute a communicative value to it.

Marianne Lederer (1994: 35-41) refers to the well-known compléments cognitifs and bagage cognitif: "Le bagage cognitif est pour l'essentiel ce qui se nomme en anglais encyclopaedic (ou world) knowledge - connaissance encyclopédique ou connaissance du monde. Il comprend toutes les connaissances, linguistiques et extra-linguistiques, emmagasinées dans la mémoire de l'individu, réactivables à tout moment par une sollicitation extérieure ou intérieure." Christine Durieux (1995: 20-22), apart from basic knowledge ("connaissances de base"), refers to specialised knowledge as "connaissances thématiques."

In Gémar's point of view "ces connaissances - que nous qualifions de 'bagage' (pour le traducteur) et qu'Umberto Eco appelle fort justement 'encyclopédie' - sont indispensables pour comprendre ce que nous lisons ou entendons" Gémar (1995: 152). C. Kerbrat-Orecchioni refers to this knowledge as "compétences culturelles" or "encyclopédiques" and "compétences idéologiques."

W. Wilss's approach (1996: 72) that "knowledge is organized in domains" and that "domain-related organization of knowledge means that when we recall information on a given domain, our memory does not supply us with a list (or set) of more or less unconnected facts, but with information in domain-specific ways," could be related to the comprehensive model of translation of Hatim and Mason $(1990,1997)$ which is grounded on the notion of text typology.

Therefore, texts are not coherent or incoherent per se. A text's coherence and acceptability are also affected by factors such as age, gender, nationality, education, employment, ideology, culture in general. To gain access to a text's content, the reader or the translator must be able to correlate text-based information to his/her own knowledge about the world, to his/her own cognitive resources, to certain global or general configurations that are stored in one's mind.

Some types of global patterns which are useful for many tasks of text processing and comprehension are frames, schemas, plans and scripts (Beaugrande and Dressler 1981: 90f.). Frames are global patterns that "contain commonsense knowledge about some central concept" such as birthday parties. Schemas are "global patterns of events and states in ordered sequences linked by time proximity and causality." Plans are "global patterns of events and states leading to an intended goal. Finally, scripts are "established plans called up very frequently to specify the roles of participants and their expected actions."

It is better to examine these concepts using examples and indicate their relation to translation teaching.

\section{Text A}

The club had two areas, a bar and a lounge. The doctor was driving. A waitress approached. I ordered drinks. Silence. I always drink vodka. People dancing around, others chatting. A couple was kissing. I need another one. 
In text $\mathrm{A}$, the frame is a night club. Every reader has some basic knowledge about a night/dance club and its characteristics. This story is not coherent, because there are interfering elements that do not match with the frame, and therefore, do not make sense. For example, the underlined sentence. Its presence surprises the reader in the first place. Then, the sentence seems to fit the co-text, as a waitress could approach the doctor by car (the verb used can justify such an explanation). However, when reading further down, it is clear that she approaches the client/narrator to take the order. Further down, the word Silence is ambiguous and not necessarily coherent. Silence in which way? Because there was no further communication between the waitress and the client or silence (in the sense of quietness) in the club? But is the second interpretation possible? Even if the music was paused or there was a power outage, commonsense experience would justify only panic and noise to prevail. Therefore, the word 'silence' somehow impedes the construction of meaning. Finally, the cohesive tie 'one' (substitution) renders interpretation more difficult, since it does not substitute an element in the immediately preceding environment. In this sense, even elements that normally help readers track the order of meanings and events (usually cohesive devices and connective links in general), many times confuse or obstruct reader, because they are used falsely or abusively. Therefore, the speaker's plan is not properly served, because certain elements do not fulfil the communicative function of the utterance.

\section{Text B}

I paid the waitress at the counter. She had already ordered. Mary was fortunately there. I was worried I wouldn't find a table. I was late.

In text $\mathrm{B}$, the initially strange reaction of the reader is due to the fact that the narration script is not served as one would normally expect; i.e., the story is presented in reverse order. In descriptions, narrations and recordings of elements and events, the most expected scenario is to follow an order that is more commonly preferred for such an occasion and not an 'extreme' one. For example, in narration it is common to present the normal order of events, which is to record events on the basis of their temporal proximity, starting from past events and actions and approaching present or future ones.

Probably, an occasional deviation from the preferred order may not affect the coherence of a text too seriously. However, minor repetitive deviations have, cumulatively, a negative effect on the reader's capacity to comprehend easily a message or part of it. Often, the way we choose to present events depends on psychological or emotional factors. Readers or listeners expect a text producer to present first the events that are close to his/her environment and experience (Brown and Yule 1983: 146).

A reader or listener of a text/message may understand the information of the text if he/she is in a position to integrate this information in a certain model for perceiving the world. Textual information may be understood only when it is correlated with other information that is already known and stored in the users' memory. This is also the case of scripts. The more a script is known to the user, the easier and more effective the processing and comprehension of the message. If the textual elements are not explicitly presented, users grasp the meaning of the utterance through inference.

For example, the extract from Bower and Hilgard 
John went to the restaurant. The steak was great. The waitress got a big tip.

is coherent, although there are no cohesive ties or leading links related to the sequence of events, temporal proximity, or relations of causality, effect and result.

However, the script, which is a dynamic schema of conventional actions, e.g., dinner in a restaurant, visit to a doctor etc., is well-known to the majority of language users. Therefore, inference is used almost subconsciously/passively by users, who know that for the waitress to receive a tip, the client must first place an order, then eat and, of course, enjoy his/her meal. In other words, the receivers of a message related to a particular social activity extract from their cognitive resources ("bagage cognitif") all the information related to it. Depending on the text, receivers resort to the respective "subtotal" of their knowledge. Knowing social activities and settings is necessary even in the case of implied meanings. In this case, receivers are able, through inference, to interpret any extract of oral or written text (Brown and Yule 1983: 233-237).

But how does all that help translators and translation students in particular in reading and comprehending a message?

It has been practically proven that the more specific the use of knowledge and information in a text, the harder it is for the translator to know in advance every possible script, frame or schema. And the less coherent a text is, the harder it is for students of translation to understand in depth, to interpret and to be able to convey/transfer the information to the target language in its entirety.

Let us now examine some examples of texts produced by translation trainees and investigate why STs, which are otherwise of a general pragmatic reference and coherent in the SL, lack their original level of coherence in the TL.

Text D [EN-EL $]^{2}$

ST: [What is World Environment Day?]

World Environment Day is a people's event with global participation. It has previously been celebrated in many ways, with people all over the world getting involved in street rallies, $[\ldots]$ school activities and tree planting as well as recycling and clean-up campaigns.

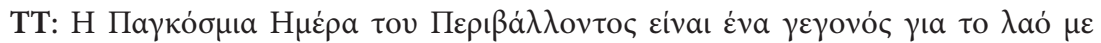

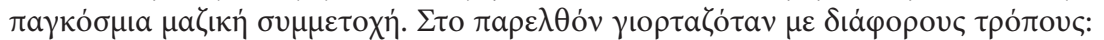

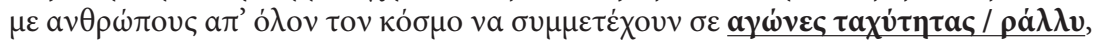

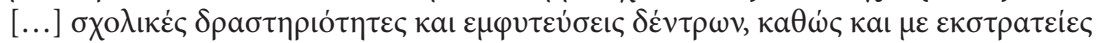

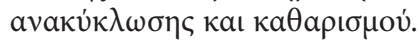

BT: The World Environment Day is an event for people with global massive participation. In the past it has been celebrated in many ways: with people from all over the world participating in races / rally competitions, [...] school activities and tree planting as well as recycling and clean-up campaigns.

Obviously, the text is about the environment and, more specifically, the World Environment Day. The text was taken from the Internet <www.environment-agency. gov.uk/wed $>$ and was given to second-year students as a mock test. In the majority of TTs, street rallies was translated as races/rally competitions. We can assume that students translate mechanically, i.e., word for word, that they probably don't know other meanings of the word rally, but also that they do not pay attention to the co-text and the overall gist of the text. Text-based knowledge combined with commonsense 
knowledge, if activated, would have led the students to ask themselves if it is possible to celebrate such a day with something burdening the environment. Therefore, in this example the coherence problem is caused due to insufficient linguistic knowledge, non-activation of common sense and, to a lesser extent, non-exploitation of textbased knowledge.

In our next translation example, also taken from the same text on the Environment Day, we can observe the following:

ST: Use mugs instead of plastic cups. At present, we could circle the equator 14 times with the number of paper and plastic cups we throw away in the UK each year.

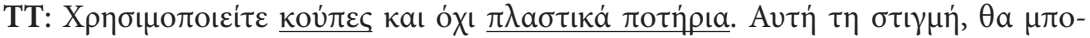

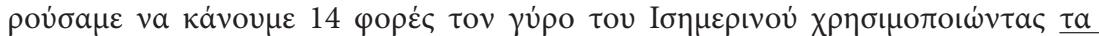

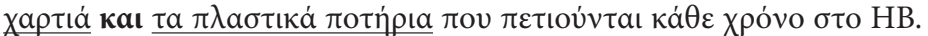

BT: Use mugs and not plastic cups. At this moment, we could make 14 times the round of the equator, using the papers and the plastic cups thrown away every year in the UK.

Students do not interpret correctly the cohesive tie - the conjunction and - which normally connects syntactically equal elements, in our case modifiers (adjectives) to the word cups. A certain number of students did not know this syntactic feature. We observe that there is no logical / semantic connection to the preceding sentence, where the word cups is mentioned in relation to the word mugs -which mostly refers to porcelain cups and not paper or plastic ones. ${ }^{3}$ In addition to this, paper was not mentioned at all in the preceding passage. Therefore, there is a local coherence problem, because text-based knowledge, co-text in particular, was not utilised.

The problematic coherence of the following example is of a different nature:

Text B (EN-EL)

ST: London Tube test for terror gas attack

On an ordinary Sunday morning, a London tube train pulls out of Bank station carrying scores of passengers reading books, browsing the newspapers or just chatting.

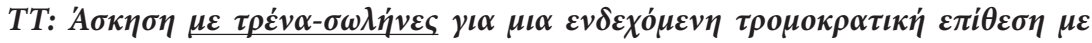
$\alpha \varepsilon \dot{\varepsilon} \iota \alpha$

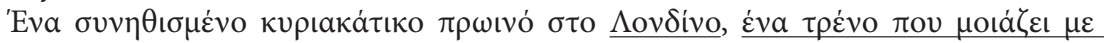

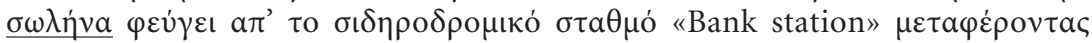

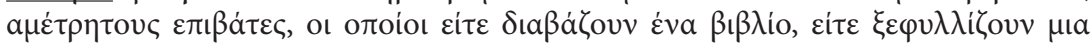

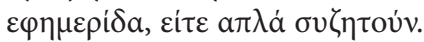

BT: Test with trains-tubes for an eventual terrorist attack with gases

An ordinary Sunday morning in London, a train which looks like a tube leaves the "Bank station" station carrying etc.

This text is from The Guardian <http://www.guardian.co.uk/terrorism/story>. The trainees' texts lack coherence, nearly overall coherence. In the example in question the lack of coherence is due to the insufficient encyclopedic, extralinguistic or social knowledge. The pragmatic reference to London, and the tube in particular, is unknown to the trainees, who translate the phrase a London tube train literally as a train which looks like a tube. These students do not ask themselves - because we think 
that they have seen or even used trains in their lives - how is it possible to have such a reference or description in a journalistic article about a test for a terror attack? Such a version could have been accepted only in fairy tales. It seems that this translation output was not opposed to the translators' knowledge about the real world, about the notion of a train. Once again, we observe the absence of reasoning and the lack of attention even to the text's title where there is a reference to London Tube. Also, textbased knowledge and co-text (e.g., black tunnel) were not utilised.

The next example is from another translation:

\section{ST: London Tube test for terror gas attack}

On an ordinary Sunday morning, a London tube train pulls out of Bank station carrying scores of passengers reading books, browsing the newspapers or just chatting.

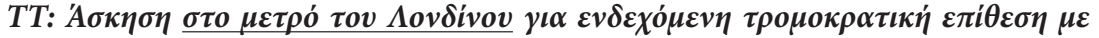
$\alpha \varepsilon \dot{\rho} \rho \iota$

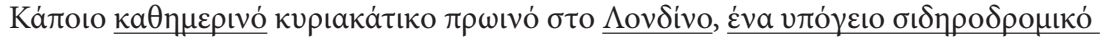

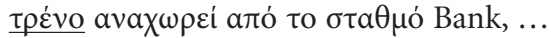

BT: Test in London's metro for possible terror gas attack

An everyday Sunday morning in London, an underground railway train pulls out of Bank station, ...

Here the pragmatic reference is known, but it is not well assimilated. The coherence problem is observed at least locally (an everyday Sunday morning) while the adjuncts to the noun train are presented in a different order. When reading the Greek version, one would wonder whether there is a non-railway train, or whether an underground train exists. Why are commonsense knowledge and logic not activated during the translation process? If they were activated during the translation process - at least in the case of general reference texts, they could help students overcome a part of their linguistic weakness and produce coherent and comprehensible texts.

How can we help translation trainees deal with such phenomena, i.e., not to produce incoherent texts, either in part, local incoherence, or in whole, overall incoherence? Certainly a text must be viewed as a dynamic entity with a network consisting of local and overall coherence (or van Dick's macrostructure).

Related research, either from the point of view of Text linguistics and Translation Studies, or Cognitive Psychology and learning studies in general, refer to coherence as being an essential factor of text comprehension. Texts, which are one of the most important vehicles of knowledge acquisition, information transfer and collection, have been the focus of translation studies for many years. More recent studies are concerned with translation as a process, thus examining various cognitive aspects related to the translator's mind and the three stages of translating, i.e., text decoding, re-expression to the target language, and translation output verification or revision. Furthermore, as McNamara (2001), suggests "understanding text comprehension [...] and understanding the processes involved in learning from text, are among the most important endeavours challenging cognitive scientists today. Early research in cognitive psychology indicated that prior knowledge was a driving factor in text comprehension." Of course, different reading strategies are employed, depending on the kind of text one is dealing with. As Beaugrande suggests (1978, cited in Hatim 2001: 116) "a gradation moving from a reading which is based predominantly on reader-supplied 
information toward a reading based predominantly on text-supplied information." The performance of different readers and their varying degrees of efficiency may be accounted for in terms of the kind of reading they do on a given occasion. The interaction between the reader and text never ceases (Hatim 2001: 113-117). Prior knowledge is considered necessary for the reader, hence the translators, in order to gain access to the text, identify coherence and the conceptual network and develop a global understanding of the text to be translated. Having less prior knowledge, professional translators or translation trainees primarily depend on the information which is explicitly presented in the text. Moreover, given that texts contain often implied meanings or have conceptual gaps, prior knowledge and their activation are definitely crucial for text understanding. Finally, we must not forget that cohesion, situationality and intertextuality are also vital in text comprehension.

Danielle McNamara, in her approaches regarding coherence, refers to the term also by assigning to it the characteristics of cohesion. A high-coherence text has fewer gaps, thus requires fewer inferences, making the text easier for understanding. According to McNamara's research (2001) and other approaches (e.g., Kintsch, Songer) it has been indicated that high-knowledge readers (with a high "bagage cognitif," to use Delisle's term) learn more from low-coherence texts, and this is due to the fact that they use their knowledge to fill the gaps - grammatical and conceptual - in the text; consequently they integrate the text they read into their prior knowledge. In her research experiments, participants read one text version, the high- or lowcoherence, twice, or both versions in a given order. When the low-coherence text was read first, the reader was 'forced' to use his/her prior knowledge to fill any conceptual gaps. However, when the high-coherence text was read first, it seemed that there was no necessity to use prior knowledge to understand the low-coherence text, when the latter was presented second. Therefore, high-knowledge readers benefited from the low-coherence text only when they read it first. Low-knowledge readers benefited from the high-coherence text, regardless of whether it was read first, second or twice (McNamara 2001).

McNamara's research findings with regard to the learning process and coherence, which of course are not limited to the aforementioned case, are of particular interest and may have important applications in studies on the translation process and translation teaching. Similar exercises, which will be adapted in translation teaching material with texts of general and specialised reference, could be of important value and usage. Moreover, the selection of the teaching material on the basis of high and low coherence could be further examined by translation teachers. In this way, high-coherence texts can be used as introductory to a particular domain, where students do not have the sufficient resources and experience regarding special language. Gradually teachers can reduce a text's coherence, i.e., make it low, so that students practise using their logic, their commonsense knowledge, the text-based knowledge and their prior knowledge in order to fill any gaps and get to the desired result, i.e., the construction of meaning and the production of coherent texts in the target language.

To sum up, let us cite Hatim and Mason (1990: 64-65) "Seeing the meaning of texts as something which is negotiated between producer and receiver and not as a static entity independent of human processing activity once it has been coded is, we believe, the key to an understanding of translating, teaching translating and judging translations." 


\section{NOTES}

1. See Batsalia and Sella (1997: 85-92). Other methods include immediate retrospection (IR), bottomup and top-down processes, construction and utilization process, etc. See Kussmaul (1995: 7-13) and Kiraly (1995).

2. ST: source text in English, TT: target text in Greek, BT: back translation from Greek.

3. One could make reference to a famous article by Labov regarding the classification of different containers/cup-like objects by research participants. [See Hatim (2004: 244-245)]. Of course, in the text in question, we don't think there is or might be a problem regarding the characterisation of a cup and a mug.

4. See also Kintsch's construction-integration model.

\section{REFERENCES}

Beaugrande, R. DE (1999): "Language, discourse, and cognition: Retrospects and prospects." Conference of the International Association of Cognitive Linguistics in Stockholm, $<\mathrm{http} / / \mathrm{www}$. beaugrande.com $>$.

Beaugrande, R. DE (1978): Factors in a Theory of Poetic Translation, Assen, Van Gorcum.

Beaugrande, R. De and W. Dressler (1981) Introduction to Text Linguistics, London, Longman. BELL, R. (1991): Translation and translating, London, Longman.

Bower, G. and E. Hilgard (1997): Theories of learning, London, Prentice Hall.

Brown, G. and G. Yule (1983): Discourse analysis, Cambridge, CUP.

Durieux, C. (1995): Apprendre à traduire. Prérequis et tests, Paris, La Maison du Dictionnaire.

Gémar, J.C. (1995): Traduire ou l'art d'interpréter. Fonctions, statut et esthétique de la traduction. Tome 1: principes, Presses de l'Université du Québec.

GiLe, D. (1995): Basic Concepts and Models for Interpreter and Translator Training, Amsterdam/ Philadelphia, John Benjamins.

Натім, B. (2001): Teaching and Researching Translation, Pearson Education, Longman.

Hatim, B. and I. Mason (1997) The Translator as Communicator, London and New York: Routledge.

Натім, B. and I. Mason (1990) Discourse and the Translator. London: Longman.

Hatim, B., Munday, J. (2004) Translation. An advanced resource book. London: Routledge.

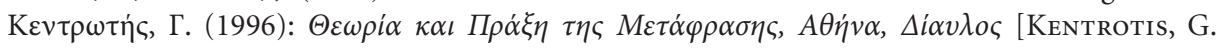
Theory and Praxis of Translation, Athens, Diavlos, in Greek].

Kiraly, D.C. (1995): Pathways to Translation. Pedagogy and Process, Kent, The Kent State University Press.

Kussmaul, P. (1995): Training the Translator, Amsterdam/Philadelphia, John Benjamins.

Lederer, M. (1994): La traduction aujourd'hui, Paris, Hachette.

McNamara, D. (2001): "Reading Both High-coherence and Low-coherence Texts: Effects of Text Sequence and Prior Knowledge," Canadian Journal of Experimental Psychology 55-1, p. 5162.

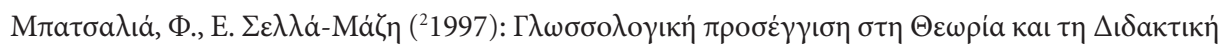

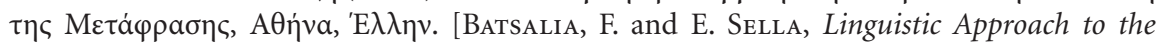
Theory and Didactics of Translation, Athens, Ellin, in Greek].

Wilss, W. (1996): Knowledge and Skills in Translator Behavior, Amsterdam/Philadelphia, John Benjamins. 